\title{
KAJIAN SOSIOPRAGMATIK IKLAN DAKWAH TENTANG RIBA
}

A Sociopragmatic Study: Islamic Proselytism Advertisement on Usury

\author{
Fatmahwati A \\ Balai Bahasa Provinsi Riau \\ Jalan HR. Soebrantas Panam KM. 12,5, Kota Pekanbaru, Riau, Indonesia \\ fatmaadnan@yahoo.com
}

Naskah Diterima Tanggal 31 Juli 2019—Direvisi Akhir Tanggal 12 Maret 2021—Disetujui Tanggal 6 Desember 2021 doi: https://doi.org/10.26499/rnh.v10i2.1622

\begin{abstract}
Abstrak
Tujuan kajian ini ialah mengetahui jenis tindak tutur dan daya pragmatik iklan dakwah tentang riba. Kajian ini menggunakan pendekatan kualitatif dengan metode deksriptif yang bersifat fenomenologis. Data iklan dakwah dikumpulkan dengan melakukan studi lapangan dan dokumentasi, sedangkan data daya pragmatik diperoleh melalui wawancara. Hasil penelitian menunjukkan bahwa pola penyampaian pesan yang terbanyak digunakan ialah tindak tutur asertif, yaitu menyatakan fakta, informasi, pengetahuan, dan hukum dengan menyertakan argumen dan bukti yang didasarkan pada Al-Qur'an dan hadis Rasulullah. Tanggapan responden menunjukkan daya pragmatik iklan dakwah tersebut. Ternyata, $46 \%$ responden "mengabaikan", 32\% "menolak", dan 22\% menerima pesan iklan dakwah itu. Simpulan yang ditarik dari kajian sosiopragmatik terhadap fenomena ini ialah masyarakat muslim cenderung "mengabaikan" pesan dakwah tentang riba karena lebih mementingkan tuntutan dan gaya hidup hedonis yang "mewabah" dewasa ini.
\end{abstract}

Kata-kata kunci: sosiopragmatik, iklan, dakwah, riba

\begin{abstract}
The purpose of this study is to find out the types of speech acts and the pragmatic power of the proselytism advertisement on usury. The qualitative approach is used in this study. The method used is the descriptive phenomenological method. Data regarding Islamic proselytism advertisements are collected from field studies and documentation, while pragmatic power data are obtained through interviews. The research findings reveal that the speech act used the most is the assertive speech act, namely presenting facts, information, knowledge, and Islamic law on usury by including arguments and evidence based on the Quran and Hadith. The data regarding the pragmatic power obtained from the respondents show that $46 \%$ of respondents "ignored", 32\% "rejected", and 22\% acknowledged the messages on the proselytism advertisements. The conclusion drawn from the sociopragmatic study of this phenomenon is that Muslims tend to "ignore" the messages about usury because of hedonistic lifestyle of today.
\end{abstract}

Keywords: sociopragmatics, advertisement, Islamic proselysm, usury

How to Cite: A, Fatmahwati. (2021). Kajian Sosiopragmatik Iklan Dakwah Tentang Riba. Ranah: Jurnal Kajian Bahasa. 10(2). 293-303. doi: https://doi.org/10.26499/rnh.v10i2.1622

\section{PENDAHULUAN}

Teknologi informasi memungkinkan iklan disampaikan dengan berbagai cara. Selain teknologi yang menawarkan banyak cara, keterbukaan informasi juga memberi peluang untuk menyampaikan berbagai pesan iklan secara terbuka di ruang publik. Praktisi komunikasi pemasaran Amerika serikat, Terence A. Shimp, menjelaskan bahwa iklan atau periklanan 
memiliki beberapa fungsi, di antaranya adalah memberikan informasi, membujuk, mengingatkan, dan memberi nilai tambah (Mahanani, 2003, hlm.17). Keberhasilan iklan melaksanakan fungsi tersebut didukung oleh sejumlah besar fitur budaya dan bahasa dalam proses komunikasi sosial.

Bahasa iklan sangat menarik untuk dikaji dari perspektif pragmatika. Austin (Cummings, 2007) mengatakan bahwa bahasa dapat digunakan untuk melakukan tindakan melalui pembedaan antara ujaran konstatif dan ujaran performatif (hlm.2). (Prayitno, 2017) mengatakan bahwa bahasa adalah tindakan. Bahasa bukan sekadar ucapan, tuturan, kalimat, atau bahkan bukan pula hanya sekadar penggunaan. Setiap ucapan, tuturan, kalimat, atau pemakaian bahasa itu mengandung kehendak dilakukan atau tidak boleh dilakukannya suatu tindakan (hlm. 1).

Birner, (2012) mengatakan bahwa pragmatika adalah "the study of language use in context" (hlm.2). Artinya, pragmatika memahami peristiwa dari konteks yang melatarinya. Hakikat konteks dijelaskan oleh Rahardi (2015) dengan mengacu pada pendapat Huang (2007), Stalnaker (1974), dan Clark (1996). Simpulan pendapat dari ketiga ahli itu ialah konteks dimaknai sebagai pengetahuan umum atau pengetahuan bersama sebagai seperangkat latar belakang asumsi yang dimiliki bersama oleh penutur dan mitra tutur. Pengetahuan bersama itu dibagi menjadi dua kategori, yaitu kesamaan komunal dan kesamaan personal (hlm. 1).

Salah satu iklan yang marak akhir-akhir ini di Kota Pekanbaru ialah iklan berisikan dakwah tentang riba. Iklan bermuatan dakwah tentang riba muncul di berbagai media, mulai dari kain rentang sampai media sosial. Iklan dakwah merupakan penyiaran agama dan pengembangannya di kalangan masyarakat; seruan untuk memeluk, mempelajari, dan mengamalkan ajaran agama yang disampaikan melalui media iklan (KBBI daring, 2016). Artinya, aktivitas penyiaran ajaran agama dilakukan secara terbuka di ruang publik yang dapat dibaca semua orang, termasuk nonmuslim. Disinyalir munculnya iklan dakwah ini merupakan "perlawanan" terhadap iklan niaga yang menawarkan riba secara terang-terangan. Memang, sebuah wacana yang menyebar luas dalam kehidupan masyarakat tidak bertolak dari imajinasi atau kekosongan. Realitas sosial dalam kehidupan melatari wacana-wacana dan peristiwaperistiwa bahasa yang beredar di masyarakat.

Riba menjadi paradoks yang mencuat di berbagai media ruang publik Kota Pekanbaru. Di satu sisi, iklan niaga mempromosikan riba secara masif dengan beragam bahasa persuasif. Di sisi lain, marak pula iklan yang bertujuan untuk mengingatkan dan mengedukasi masyarakat tentang hukum riba dalam tuntunan agama Islam. Diyakini bahwa kehadiran iklan dakwah tentang riba merupakan upaya mendidik masyarakat agar memahami persoalan riba dengan lebih baik. Pada tataran yang lebih tinggi diharapkan iklan dakwah ini difungsikan untuk mengingatkan masyarakat agar menjauhi perbuatan yang mengandung unsur riba. Menurut Shofaa dan Utami (2017), iklan mengandung nilai-nilai ideologi yang disampaikan secara implisit. Pada dasarnya iklan memuat persuasi yang berusaha meningkatkan citra produk. Secara tidak langsung iklan berdampak pada psikologi konsumen sehingga mereka secara tidak sadar "setuju" pada pesan yang disampaikan dalam sebuah iklan (hlm. 180).

Berdasarkan situasi maraknya iklan riba yang bersaing dengan iklan dakwah, kajian ini mengacu pada konsep sosiopragmatik. Secara sederhana dapat dikatakan bahwa dengan mengacu pada konsep sosiopragmatik, kajian ini membahas dua hal, yaitu kebahasaan (tindak tutur) dan respons masyarakat (daya pragmatik).

Penelitian terkait yang menggunakan pendekatan sosiopragmatik di antaranya ditulis oleh Wicaksono (2015), Masran (2018), dan Rahmayanti (2020). Wicaksono (2015) melakukan penelitian yang bertujuan untuk mendeskripsikan bentuk dan konteks sosial tuturan yang digunakan untuk menyatakan tindak tutur komisif dalam pementasan drama Mangir Wanabaya. Hasil penelitian membuktikan bahwa bentuk tindak tutur komisif pementasan drama Mangir Wanabaya dapat berupa kata, 
predikat propositif, dan konteks yang menyatakan komisif. Tindak tutur komisif yang didapat ialah tindak tutur komisif berniat, berjanji, bersumpah, dan bernadar (hlm. 73-86).

Penelitian terkait lainnya ditulis oleh Masran (2018). Penelitian yang mengkaji papan iklan yang ada di Kota Kuala Lumpur ini menggunakan metode observasi dan teknik simak catat. Mengacu pada tindak tutur ilokusi Searle, hasil penelitian menunjukkan bahwa tidak terdapat tindak tutur asertif, direktif, ekspresif, dan komisif. Semua pesan iklan disampaikan dengan tindak tutur ilokusi deklaratif (hlm. 244-254).

Selanjutnya, penelitian yang berjudul "Sosiopragmatik Imperatif Iklan pada Media Sosial" oleh Rahmayanti dan Alvi Fajar (2020) menganalisis iklan media sosial Instagram, Facebook, dan Line terbitan bulan April-Mei 2018. Hasil analisis data menunjukkan bahwa terdapat 19 iklan sosiopragmatik imperatif biasa, 2 iklan yang tergolong tuntutan, 9 iklan ajakan, 11 iklan tatanan, dan tidak ditemukan iklan perizinan. Artinya, bentuk sosiopragmatik yang muncul ialah imperatif biasa (hlm. 79-86).

Berbeda dengan ketiga penelitian tersebut, kajian ini membahas jenis tindak tutur penyampaian pesan dan efeknya terhadap masyarakat pembaca iklan. Masalah kajian ini dirumuskan sebagai berikut: (1) bagaimanakah tindak tutur pesan dakwah itu disampaikan? dan (2) bagaimanakah daya pragmatik iklan dakwah itu dalam memengaruhi sikap masyarakat?

\section{LANDASAN TEORI}

Menurut Leech (1993: 16), pragmatika merupakan ilmu yang bisa bergerak ke dalam (bahasa) dengan mengkaji tata bahasa melalui pragmalinguistik dan dapat pula bergerak ke luar (bahasa) dengan mengkaji aspek sosiologi melalui sosio-pragmatik. Thomas (1995: 22) mengartikan pragmatika sebagai "bidang yang mengkaji makna dalam interaksi". Dengan demikian dapat dikatakan bahwa interaksi berbahasa tidak terlepas dari kondisi sosial yang melingkungi penutur dan petutur. Menurut Leech (1993: 16), kajian yang bergerak ke luar bahasa dengan meninjau aspek sosial dapat dilakukan melalui sosiopragmatik. Sosiopragmatik merupakan titik temu antara sosiologi dan pragmatika. Dengan kata lain, sosio-pragmatik lebih mengarah pada kajian pragmatik yang berkaitan dengan kondisi sosial tertentu.

Rahardi (2009) menggarisbawahi perbedaan mendasar antara pragmatik dan sosiopragmatik. Kajian pragmatik didasarkan pada konteks situasi, sedangkan sosio-pragmatik didasarkan pada konteks sosial dan situasional. Jadi, sosio-pragmatik dapat diartikan sebagai kajian mengenai maksud tuturan yang berhubungan dengan aspek-aspek sosial yang melingkupi terjadinya tuturan tersebut, seperti kebudayaan dan masyarakat, bahasa, situasisituasi sosial, kelas-kelas sosial, dan lain-lain (hlm. 1).

Dalam bertutur terdapat tindakan yang dilakukan dengan cara tertentu untuk mencapai maksud tertentu. Yule (2016) mengartikan tindak tutur sebagai tindakan-tindakan yang ditampilkan lewat tuturan (hlm. 82). Kreidler (1998) membedakan bentuk-bentuk tindak tutur dalam tujuh kategori, yaitu asertif, performatif, verdiktif, ekspresif, direktif, komisif, dan fatis. Daya pragmatik dibentuk oleh daya ilokusi dan daya retorik secara bersama-sama. Daya retorik adalah makna tuturan dilihat dari ketaatan penutur pada prinsip-prinsip retorik (misalnya sejauh mana penutur mengatakan yang benar, berbicara dengan sopan, atau bernada ironis) (hlm. 183-184). Daya pragmatik berkaitan dengan interpretasi atas tuturan (Leech, 1993). Secara sederhana dapat didefinisikan bahwa daya pragmatik berkaitan dengan dampak atau pengaruh teks atau tuturan yang signifikan terhadap pembaca atau pendengar (hlm. 23).

Riba, menurut mayoritas ahli tafsir (jumhûr al-mufassirîn) adalah suatu bentuk pemberian (al-'athiyyah) yang disampaikan seseorang kepada orang lain, bukan dengan tujuan untuk menggapai rida Allah Swt., tetapi hanya sekadar untuk mendapatkan imbalan duniawi semata (Syarief, 2011: 293). Lebih lanjut (Syarief, 2011), menjelaskan tiga dampak negatif riba yang didasarkan pada Surah Albaqarah 275-280. Pertama, riba menjadikan pelakunya laksana orang 
yang kerasukan setan, sehingga tidak dapat lagi membedakan antara yang hak dengan yang bâthil, seperti tidak dapat membedakan jual-beli yang jelas-jelas halal dengan riba yang nyatanyata haram. Kedua, dalam riba terdapat unsur zhulm (penindasan terhadap orang lain) yang tidak ada pada jual-beli. Karena itu, jual-beli halal, sementara riba haram dilakukan. Ketiga, pada hari kiamat nanti pemakan riba akan mendapat siksa yang kekal abadi dalam neraka.

\section{METODE PENELITIAN}

Kajian ini menggunakan pendekatan kualitatif dengan metode deskriptif. Data kajian ini ialah (1) iklan bermuatan dakwah tentang riba yang tersebar pada media ruang publik dan (2) respons masyarakat terhadap iklan itu. Mengingat kuantitas data iklan yang sangat besar, sampel ditentukan dengan teknik purposive sampling yang ditentukan secara acak. Data respons masyarakat dikumpulkan melalui wawancara terbuka dengan memperlihatkan data iklan terlebih dahulu. Instrumen yang digunakan ialah daftar pertanyaan untuk mengetahui daya pragmatik teks iklan.

Data iklan dianalisis dengan mengklasifikasikannya dalam jenis tindak tutur, selanjutnya dihitung untuk mengetahui frekuensi, kemudian dibahas dengan mengacu pada teori tindak tutur, dan terakhir disimpulkan. Data respons masyarakat dianalisis dengan menghitung hasil kuesioner, menabulasi hasil sesuai kategori jawaban (menerima, menolak, mengabaikan), membahas dengan mengacu pada teori daya pragmatik, dan menyimpulkan.

Kajian ini merupakan kajian fenomenologis yang menggambarkan arti sebuah konsep atau fenomena. Menurut Littlejohn dan Foss (2005), fenomenologi berfokus pada pengalaman personal, termasuk bagaimana para individu mengalami satu sama lain. Oleh karena itu, komunikasi dipandang sebagai hubungan antarpribadi secara bersama melalui dialog (hlm. 13). Peneliti berperan sebagai observer partisipan yang terlibat secara aktif dalam menggali data penelitian. Responden adalah masyarakat Kota Pekanbaru yang dipilih secara acak.

\section{PEMBAHASAN}

Secara sistematis, uraian pembahasan kajian ini dibagi dalam dua bagian. Pertama, analisis jenis tindak tutur untuk mengetahui pola penyampaian pesan iklan dakwah. Kedua, daya pragmatik untuk mengetahui pengaruh atau dampak signifikan teks iklan.

\section{Jenis Tindak Tutur}

Hasil analisis menunjukkan bahwa ketujuh jenis tindak tutur konsep Kreidler ditemukan pada data dengan jumlah yang variatif. Ternyata, jenis tindak tutur yang terbanyak digunakan ialah asertif. Asertif disampaikan dengan menggunakan kalimat berita yang memuat pengetahuan tentang gagasan yang disampaikan. Pesan dakwah asertif disampaikan dengan mengungkapkan imbauan yang disertai pengetahuan atau informasi.

Hasil analisis juga memperlihatkan bahwa satu iklan dakwah yang memuat lebih dari satu kalimat cenderung menggunakan tindak tutur yang berbeda. Misalnya, kalimat pertama bersifat verdiktif, sedangkan kalimat kedua bersifat asertif. Artinya, pembuat iklan menggunakan strategi penyampaian pesan yang disesuaikan dengan tujuan yang ingin dicapai. Kalimat pertama ditujukan untuk memancing perhatian pembaca, sedangkan kalimat kedua dimaksudkan untuk memperkuat argumen. Penguatan argumen dapat dilakukan dengan pencantuman ayat suci Al-Qur'an dan hadis nabi.

Bentuk tindak tutur pesan dan strategi penyampaian merupakan faktor penting yang memengaruhi keberterimaan pesan oleh pembaca. Hasil analisis jenis tindak tutur iklan dakwah tentang riba dapat dilihat pada tabel berikut. 
Tabel 1.

Jenis Tindak Tutur

\begin{tabular}{|c|c|}
\hline Teks Iklan Dakwah & Tindak Tutur \\
\hline Say no to riba & Direktif \\
\hline $\begin{array}{l}\text { Anda butuh modal? } 1 \text { jam cair. Syarat pinjaman BPKB/ sertifikat tanah. Jaminan siksa neraka. } \\
\text { Hubungi QS 2:275. }\end{array}$ & Komisif \\
\hline $\begin{array}{l}\text { Malulah ketika kita pura-pura kaya, padahal dari hutang riba. "Tak seorang pun memper- } \\
\text { banyak (harta kekayaannya) dari hasil riba, melainkan pasti akibat akhirnya akan jatuh miskin } \\
\text { (HR. Ibnu Majah) }\end{array}$ & $\begin{array}{l}\text { Direktif } \\
\text { Asertif }\end{array}$ \\
\hline $\begin{array}{l}\text { Dosanya "Nge RIBA nget". Riba itu memiliki } 73 \text { pintu, yang paling ringan dosanya adalah } \\
\text { seperti seseorang yang menzinahi ibunya sendiri. }\end{array}$ & $\begin{array}{l}\text { Ekspresif } \\
\text { Asertif }\end{array}$ \\
\hline Hutang riba untuk membayar bunga riba? Inilah Indonesia. & Verdiktif \\
\hline $\begin{array}{l}\text { Seringan apa pun bunganya, sekecil apa pun dendanya, riba tetaplah riba. "Orang-orang yang } \\
\text { makan (mengambil) riba tidak dapat berdiri melainkan seperti berdirinya orang yang } \\
\text { kemasukan syaitan lantaran tekanan (penyakit) gila. QS Albaqarah/2: } 275 \text {. }\end{array}$ & $\begin{array}{l}\text { Ekspresif } \\
\text { Asertif }\end{array}$ \\
\hline Bebaskan diri Anda dari jerat hutang dan riba. & Direktif \\
\hline Allah mengharamkan riba tapi kamu masih ngotot menawarnya. Apakah bagimu pekerjaan & Ekspresif \\
\hline jauh lebih penting dari Nya? & Ekspresif \\
\hline $\begin{array}{l}\text { Hidup mulia tanpa riba. Udah gunting aja. Rezeki dari Allah itu cukup untuk hidup, tapi tak } \\
\text { akan cukup untuk gaya hidup. }\end{array}$ & $\begin{array}{l}\text { Fatis } \\
\text { Direktif } \\
\text { Ekspresif }\end{array}$ \\
\hline $\begin{array}{l}\text { Sampai kapan engkau berikan keluarga, istri/suami, dan anak-anakmu harta riba? Rasulullah } \\
\text { bersabda: Tidak akan masuk surga daging yang tumbuh dari makanan yang haram dan neraka } \\
\text { lebih layak baginya (HR. Ahmad 3/321). }\end{array}$ & $\begin{array}{l}\text { Verdiktif } \\
\text { Asertif }\end{array}$ \\
\hline $\begin{array}{l}\text { DEBU RIBA: dari Abu Hurairah, Rasulullah bersabda "Suatu saat nanti manusia akan } \\
\text { mengalami suatu masa yang ketika itu semua orang memakan riba. Yang tidak makan secara } \\
\text { langsung akan makan debunya." }\end{array}$ & Asertif \\
\hline $\begin{array}{l}\text { Allah melaknat pemakan riba, orang yang memberi makan dengan (hasil) riba, pencatatnya, } \\
\text { serta kedua saksinya (HR. Muslim). }\end{array}$ & Asertif \\
\hline $\begin{array}{l}\text { Lingkaran (debu) riba di sekitar kita: bank, asuransi, dana pensiun, jaminan sosial, } \\
\text { jaminan/asuransi kesehatan, gaji/tunjangan/bonus. }\end{array}$ & Asertif \\
\hline $\begin{array}{l}\text { Masih makan riba, sungguh hidupmu mengenaskan. "Riba ada } 73 \text { tingkatan. Yang paling } \\
\text { ringan adalah seperti (dosa) menzinai ibu kandung sendiri (HR. Al Hakim dan dinyatakan } \\
\text { sahih beliau dan Al Abany). }\end{array}$ & $\begin{array}{l}\text { Verdiktif } \\
\text { Asertif }\end{array}$ \\
\hline $\begin{array}{l}\text { Stop riba: rumahnya KPR, modalnya pinjaman bank, kendaraannya leasing, asset dan jiwanya } \\
\text { diasuransikan, belanja-nya dengan kartu kredit, bisnisnya MLM, di kantornya buat koperasi, } \\
\text { investasinya di pasar saham, hajinya pakai dana talangan. "Tidaklah seseorang membiasakan } \\
\text { riba kecuali Allah membalasnya dengan keku-rangan" (HR. Ibnu Majah } 2279 \text { dan disahihkan } \\
\text { oleh Al Abany dalam Sohih Al Jami': 5518). }\end{array}$ & $\begin{array}{c}\text { Direktif } \\
\text { Asertif }\end{array}$ \\
\hline $\begin{array}{l}\text { Ditantang perang oleh Allah dan rasul-Nya. "Maka jika kamu tidak mengerjakan (mening- } \\
\text { galkan) sisa riba, maka ketahuilah bahwa Allah dan rasul-Nya akan memerangimu. Dan jika } \\
\text { kamu bertaubat (dari pengambilan riba), maka bagimu pokok hartamu, kamu tidak } \\
\text { menganiaya dan tidak (pula) dianiaya." }\end{array}$ & $\begin{array}{c}\text { Komisif } \\
\text { Asertif }\end{array}$ \\
\hline Bahaya riba: membuat segala-nya jadi mahal, usaha pun jadi susah. & Verdiktif \\
\hline $\begin{array}{l}13 \text { fakta tentang riba yang muslim harus paham. Sudah rajin sholat, sudah rajin zakat dan } \\
\text { sedekat, sudah rajin puasa, sudah rajin baca Alquran, sudah rajin beramal sholih, sudah umroh }\end{array}$ & $\begin{array}{l}\text { Asertif } \\
\text { Ekspresif }\end{array}$ \\
\hline $\begin{array}{l}\text { bahkan berhaji Tapi kok rasanya rezeki kurang terus ya, kok utang tambah banyak ya, kok } \\
\text { ikhtiar sering berantakan, bahkan mentok ya, kok masalah datang terus ya. Coba cek, siapa } \\
\text { tahu ada dosa riba yang kita lakukan. }\end{array}$ & Verdiktif \\
\hline $\begin{array}{l}\text { Kita tidak berdosa ketika kita tidak punya rumah, namun kita akan berdosa jika punya rumah } \\
\text { dengan cara riba. }\end{array}$ & Fatis \\
\hline $\begin{array}{l}\text { Riba hanya indah di permukaan. "Wahai orang-orang yang beriman, janganlah kamu } \\
\text { memakan riba dengan berlipat ganda dan bertakwalah kamu kepada Allah supaya kamu } \\
\text { mendapat keberuntungan (QS } 3 \text { Ali Imran: 130). }\end{array}$ & $\begin{array}{l}\text { Fatis } \\
\text { Asertif }\end{array}$ \\
\hline Keajaiban itu terjadi setelah berazam bebas riba. & Performatif \\
\hline Jangan malu terlihat miskin, tapi malulah ketika kita pura-pura kaya dengan cara riba. & Ekspresif \\
\hline $\begin{array}{l}\text { Terlihat kaya dari hutang riba, padahal sesungguhnya miskin dan selalu merasa kekurangan. } \\
\text { Kasihan deh lu..... }\end{array}$ & Ekspresif \\
\hline Riba: sengsara di dunia akhirat. & Fatis \\
\hline Riba itu tiket ke neraka. & Ekspresif \\
\hline Stay away from riba. & Direktif \\
\hline Hidup tanpa riba & Fatis \\
\hline
\end{tabular}

Sumber: media ruang publik (spanduk, baliho, face book, instagram) 
Data pada tabel tersebut menunjukkan bahwa terdapat 12 tindak tutur asertif, 9 ekspresif, 6 direktif, 5 verdiktif, 5 fatis, 2 komisif, dan 1 performatif. Jenis tindak tutur yang paling banyak digunakan adalah asertif.

Pesan asertif dinyatakan dengan fakta, informasi, pengetahuan, data, apa yang terjadi dan tidak terjadi. Tuturan asertif bersifat memberitahu atau menginformasikan sesuatu. Pembuat pesan berupaya meningkatkan daya pragmatik pesan dengan cara intelektual. Efek lain yang dimunculkan dari penyampaian pesan dengan tindak tutur asertif ini ialah penilaian pembaca terhadap pesan cenderung positif karena mengandung pengetahuan yang memperkaya wawasan mereka. Beberapa iklan dakwah tentang riba menyertakan ayat suci Al-Qur'an dan hadis Rasulullah untuk memperkuat gagasan. Bagi umat Islam, tentu saja Al-Qur'an atau hadis nabi sudah menjadi pedoman yang tidak diragukan lagi. Contoh tindak tutur asertif iklan dakwah pada media ruang publik sebagai berikut.

\footnotetext{
"Wahai orang-orang yang beriman, janganlah kamu memakan riba dengan berlipat ganda dan bertakwalah kamu kepada Allah supaya kamu mendapat keberuntungan (QS 3 Ali Imran: 130).

"Tidaklah seseorang membiasakan riba kecuali Allah membalasnya dengan kekurangan" (HR. Ibnu Majah 2279 dan disahihkan oleh Al Abany dalam Sohih Al Jami': 5518).
}

Pengetahuan yang disampaikan melalui pesan dakwah ini adalah firman Allah Swt (QS 3 Ali Imran: 130) dan hadis Nabi Muhammad Saw tentang riba. Tindak tutur bermuatan dakwah yang mengangkat ayat-ayat Al-Qur'an dan hadis nabi memperlihatkan bahwa pesan tidak mungkin dibantah oleh pembaca. Bagi umat Islam, Al-Qur'an dan hadis merupakan sumber ilmu dan hukum yang bersifat mutlak, tidak perlu dikontroversikan lagi.

Berdasarkan temuan itu dapat dikatakan bahwa pembuat iklan bermaksud memberi pengetahuan dan peringatan tentang riba. Diperkirakan maraknya praktik penggunaan riba dewasa ini karena kurangnya pengetahuan keagamaan atau bisa juga karena mengabaikan tuntunan agama tersebut. Berarti, fungsi iklan dakwah tersebut adalah memberikan informasi (informing) yang mungkin baru bagi pembaca atau mengingatkan (reminding) kembali pada pembaca yang sudah mengetahui sebelumnya.

Jenis tindak tutur berikutnya pada iklan dakwah tentang riba adalah ekspresif yang berjumlah 9 kalimat. Kalimat ekspresif memuat pernyataan yang pada dasarnya mencerminkan kondisi psikologis. Pembuat pesan meminta pembaca untuk mengevaluasi pernyataan tersebut. Selanjutnya, ia berharap pembaca mempercayai pesan tersebut dan bertindak sesuai pesan yang dibacanya.

Kalimat ekspresif menyiratkan adanya keinginan pembuat pesan untuk mengungkapkan gagasan dengan menyertakan perasaan individu. Kalimat ekspresif mengandung "emosi" tertentu yang diungkapkan dengan tujuan menyatakan sikap, menyindir, mengejek, memuji, dan ungkapan emotif lainnya. Berikut ini contoh kalimat ekspresif pada iklan dakwah tentang riba.

Rezeki dari Allah itu cukup untuk hidup, tapi tak akan cukup untuk gaya hidup.

Terlihat kaya dari hutang riba, padahal sesungguhnya miskin dan selalu merasa kekurangan.

Kasihan deh lu ....

Kalimat pertama menggambarkan kegeraman pembuat pesan dakwah pada sekelompok orang yang menempuh berbagai cara untuk memenuhi gaya hidup tertentu. Kalimat yang digunakan mengandung sindiran yang menyiratkan emosi pembuat iklan. Begitu pula dengan kalimat kedua, sangat dirasakan adanya emosi pembuat pesan kepada orang-orang yang menggunakan riba dalam kehidupan mereka. Apalagi adanya kalimat "Kasihan deh lu...", tergambar emosi yang dikemukakan secara jujur dan gamblang. Kalimat yang menggunakan tindak tutur ekspresif dianggap paling tepat untuk mengungkapkan perasaan atau emosi tertentu yang dirasakan oleh pembuat pesan. 
Sebenarnya tindak tutur ekspresif tidak hanya untuk kalimat bernuansa "negatif"; pembuat pesan juga dapat menggunakan kalimat yang bersifat menyatakan kekaguman atau memuji secara ekspresif. Akan tetapi, tindak tutur ekspresif tersebut tidak ditemukan pada data kajian ini. Pesan ekspresif umumnya ditujukan kepada responden yang tergolong muda (20-40 tahun). Hal ini terlihat dari gaya bahasa yang digunakan. Bahasa yang digunakan adalah ragam tak resmi, yaitu bahasa pergaulan yang biasanya digunakan oleh kaum muda. Hal ini dapat dilihat dari pilihan kata, gaya bahasa yang digunakan, dan kekomunikatifan pesan. Salvador (2003) mengatakan bahwa pertimbangan variasi linguistik melekat pada pragmatik, terutama yang berkaitan dengan faktor-faktor kontekstual, suatu area yang sering menyatu dengan gaya bahasa (hlm. 1).

Tindak tutur penyampaian pesan iklan dakwah berikutnya ialah direktif. Tindak tutur direktif pada dasarnya dilakukan oleh pembuat pesan dengan tujuan agar mitra tutur atau pembaca melakukan suatu tindakan atau mengulangi tindakannya. Agar pembaca pesan melakukan tindakan sesuai isi pesan, pembuat pesan memilih cara penyampaian dan isi pesan yang dinilai paling sesuai. Menyimak kalimat yang tergolong direktif dapat disimpulkan bahwa tindak tutur ini cenderung menggunakan verba yang bersifat imperatif berupa kalimat perintah.

Say no to riba

Malulah ketika kita pura-pura kaya, padahal dari hutan riba.

Bebaskan diri Anda dari jerat hutan dan riba.

Udah gunting aja.

Stop riba.

Stay away from riba.

Dilihat dari ragam bahasa yang digunakan kalimat-kalimat imperatif tersebut bersifat nonformal. Dari enam kalimat direktif tersebut terdapat tiga kalimat yang menggunakan bahasa Inggris. Artinya, pesan dakwah ini ditujukan pada kalangan yang terbiasa atau mengenal bahasa Inggris. Secara implisit terefleksikan bahwa kalangan yang dominan "bermain" riba adalah kalangan terpelajar dan hidup di perkotaan. Kalimat-kalimat direktif ini menyampaikan pesan yang bersifat ekspresif dan tidak menyebutkan dalil atau argumen yang bertolak dari Al-Qur'an dan hadis. Akan tetapi, secara tersirat dapat dikatakan bahwa pembuat pesan dakwah menganggap pembaca sudah mengetahui hukum riba, hanya saja perlu diingatkan kembali melalui pesan itu.

Ditengarai bahwa penggunaan tindak tutur direktif dimaksudkan agar pesan yang disampaikan diterima dan dipahami dengan mudah oleh pembaca, bahkan berefek secara positif. Sebab, tindak tutur direktif menyampaikan pesan berupa perintah atau nasihat secara jelas, langsung, dan tegas. Iklan dakwah pada media ruang publik berikutnya menggunakan tindak tutur verdiktif dan fatis. Keduanya masing-masing berjumlah lima iklan.

Tindak tutur verdiktif mengacu pada peristiwa atau perbuatan yang telah terjadi atau bersifat retrospektif. Biasanya terdapat pernyataan yang bertolak dari apa yang pernah terjadi. Lalu, dimunculkan gagasan yang dapat berupa pernyataan atau pertanyaan yang bersifat imbauan untuk direnungkan.

Hutang riba untuk membayar bunga riba? Inilah Indonesia.

Peristiwa yang terjadi ialah utang riba digunakan untuk membayar bunga riba. Kalimat ini disampaikan dalam bentuk pertanyaan yang mengusik pemikiran pembaca. Gagasan kedua dimunculkan dengan pernyataan "Inilah Indonesia" menyiratkan bahwa kondisi ini terjadi di Indonesia dan dilakukan oleh masyarakat muslim Indonesia. Ada nuansa mengejek yang bertujuan untuk mengajak pembaca melakukan introspeksi atas perbuatan yang telah dilakukan.

Sampai kapan engkau berikan keluarga, istri/suami, dan anak-anakmu harta riba? 
Peristiwa yang terjadi adalah pelaku memberi keluarganya harta riba. Ajakan untuk instrospeksi disampaikan dalam kalimat tanya. Frasa "sampai kapan" mengandung nuansa makna yang sangat keras mengingatkan pembaca iklan untuk segera menghentikan perbuatannya.

Selain verdiktif, tindak tutur fatis juga ditemukan sejumlah lima kalimat. Kalimat fatis bertujuan untuk memelihara hubungan simpatik dan akrab di antara anggota masyarakat yang tidak sama.

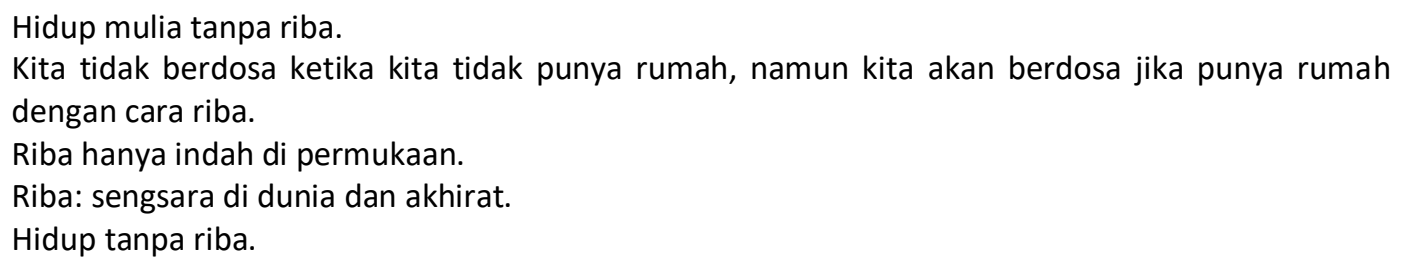

Secara pragmatis kelima kalimat tersebut terasa ringan dan tidak menimbulkan emosi tertentu yang bersifat negatif. Akan tetapi, jika kalimat tersebut dipahami secara mendalam, pada dasarnya pesan yang terkandung di dalamnya sangat keras dan tegas. Meskipun sebenarnya pesan tersebut sangat keras, tindak tutur fatis "melembutkan" kalimat tersebut sehingga tidak merusak hubungan sosial pembuat dan pembaca pesan. Tindak tutur fatis dimaksudkan untuk memengaruhi pembaca agar berbuat seperti isi pesan, tetapi dengan penyampaian yang halus dan santun. Pesan dakwah berikut ini menggunakan tindak tutur komisif.

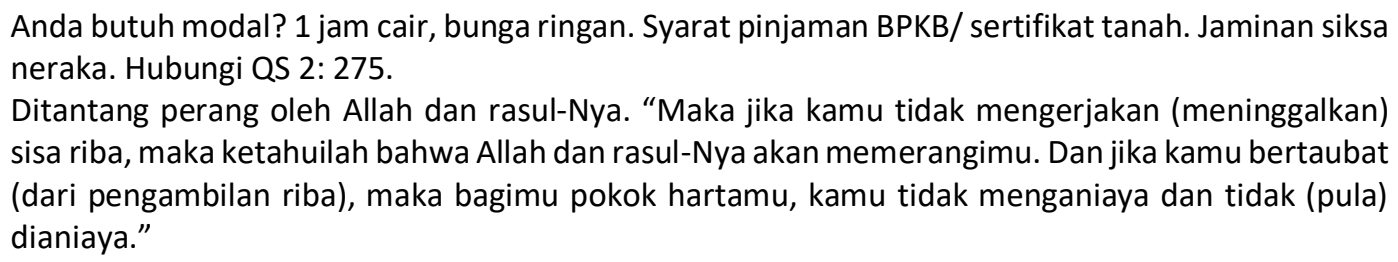

Kalimat pertama menggunakan ungkapan yang biasa digunakan oleh para pengiklan lembaga peminjaman. Secara pragmatis mengungkapkan "akibat" yang akan diterima jika meminjam uang dengan riba. Pesan dakwah disampaikan dengan keras tetapi didasarkan pada hukum yang kuat, yaitu ayat Al-Qur'an.

Kalimat kedua mengandung ancaman berupa perang dengan Allah dan rasul-Nya. Kalimat ini dinukil dari Surah Albaqarah ayat 279. Tindak tutur komisif mengikat pembaca untuk melakukan apa yang disebutkan di dalam ujarannya. Seringkali tindak tutur komisif menggunakan kalimat yang mengandung ancaman atau tantangan yang akan didapat di masa datang.

Agar ancaman tersebut berdaya pragmatik (memiliki kemampuan) untuk "memaksa" pembaca bertindak, digunakan beberapa strategi penyampaian pesan. Strategi terbaik tentu saja menggunakan ayat Al-Qur'an dan hadis nabi yang merupakan kebenaran mutlak dalam agama Islam. Pembuat pesan merasa tidak perlu menyampaikan argumen, tetapi langsung mengandalkan sumber utama hukum dan ajaran Islam. Jenis tindak tutur yang terakhir adalah performatif. Ditemukan hanya satu kalimat performatif pada iklan dakwah tentang riba yang dijadikan sebagai sampel kajian ini.

Keajaiban itu terjadi setelah berazam bebas riba.

Tindak tutur performatif mengarah pada suatu tindakan yang menyebabkan terjadinya sesuatu. Penyampaian pesan dengan tindak tutur ini bertujuan untuk mendorong pembaca agar melakukan suatu tindakan sesuai pesan dakwah. 
Ditinjau dari diksi yang digunakan, kalimat tersebut sangat inspiratif dan memesona. Sebuah dakwah yang disampaikan secara persuasif, halus, santun, dan indah. Kata "keajaiban" merupakan diksi yang sangat tepat untuk menyentuh hati pembaca. Setiap orang tentu saja menginginkan keajaiban dalam hidupnya, sebab keajaiban mengubah dari kondisi yang tidak menyenangkan ke kondisi yang diinginkan. Akan tetapi, mengapa pesan dakwah iklan tentang riba lebih dominan menggunakan tindak tutur asertif? Secara sosiopragmatik dapat dikemukakan bahwa kecenderungan ini disebabkan adanya anggapan perlunya penyampaian informasi atau pengetahuan tentang riba kepada masyarakat. Tuturan asertif memudahkan pembuat pesan untuk berdakwah dengan menyampaikan pesan yang bersifat informatif dan mengingatkan.

\section{Daya Pragmatik}

Daya pragmatik iklan dakwah tentang riba merupakan kemampuannya dalam memengaruhi sikap pembaca. Pengukuran daya pragmatik ditinjau dari respons pembaca iklan berupa tanggapan dan ekspresi. Tanggapan merupakan respons eksplisit yang diambil dari jawaban lisan, sedangkan ekspresi dijadikan sebagai respons implisit responden. Terdapat 50 orang responden yang ditentukan secara acak dan berasal dari berbagai latar belakang pekerjaan.

Penggunaan tindak tutur yang berbeda dimaksudkan untuk pencapaian tujuan yang berbeda pula. Setiap pesan memiliki tujuan tertentu. Pesan itu juga diharapkan mampu "menggerakkan" penerima pesan untuk bertindak sesuai isi pesan. Inilah yang dimaksud dengan daya pragmatik.

Secara garis besar ditemukan tiga klasifikasi jawaban, yaitu menerima, menolak, dan mengabaikan. Ketiga klasifikasi tersebut masing-masing dibagi dalam tiga kategori berdasarkan respons implisit yang diperlihatkan responden. Pertama, menerima dengan respons implisit senang, malu, dan tidak terdeteksi. Kedua, menolak dengan respons implisit marah, yakin, dan tidak peduli. Ketiga, mengabaikan dengan respons implisit malu, enggan, dan tidak terdeteksi.

Berikut ini rangkuman daya pragmatik berdasarkan respons responden (eksplisit dan implisit) terhadap iklan dakwah tentang riba.

Tabel 2

Daya Pragmatik Iklan Dakwah

\begin{tabular}{|c|c|c|c|c|}
\hline \multicolumn{5}{|c|}{ Respons Responden } \\
\hline \multicolumn{2}{|c|}{ Eksplisit } & \multicolumn{2}{|c|}{ Implisit } & \multirow[b]{2}{*}{ Persentase } \\
\hline Tanggapan & Jumlah & Ekspresi & Jumlah & \\
\hline & & Senang & 2 & $4 \%$ \\
\hline \multirow[t]{3}{*}{ Menerima } & 11 & Malu & 6 & $12 \%$ \\
\hline & & Tidak terdeteksi & 3 & $6 \%$ \\
\hline & & Marah & 9 & $18 \%$ \\
\hline \multirow{3}{*}{ Menolak } & 16 & Yakin & 2 & $4 \%$ \\
\hline & & Tidak peduli & 5 & $10 \%$ \\
\hline & & Malu & 12 & $24 \%$ \\
\hline \multirow[t]{2}{*}{ Mengabaikan } & 23 & Enggan & 9 & $18 \%$ \\
\hline & & Tidak terdeteksi & 2 & $4 \%$ \\
\hline
\end{tabular}

Sumber: hasil wawancara (Januari-Februari 2019)

Berdasarkan data pada tabel tersebut dapat dikemukakan bahwa 11 orang atau $22 \%$ responden menerima iklan dakwah. Respons implisit menerima dengan senang sebanyak 4\%, artinya mereka merasa diberi tahu atau diingatkan oleh iklan dakwah tersebut. Alasan merasa senang karena menganggap dakwah yang disampaikan iklan tersebut sangat penting bagi mereka. Ke depan mereka akan lebih berhati-hati dan berupaya untuk memahami dengan baik tuntunan agama Islam. 
Respons menerima dengan rasa malu sejumlah $12 \%$. Responden dalam kategori ini menerima dengan baik pesan dakwah yang disampaikan melalui iklan. Rasa malu muncul karena menilai diri sendiri belum mampu melaksanakan tuntunan agama tentang riba. Mereka mengetahui pesan dakwah tersebut benar dan seharusnya dilaksanakan, tetapi mereka masih melanggar hukum penggunaan riba.

Sejumlah 6\% tanggapan menerima selanjutnya adalah tidak terdeteksi. Maksudnya, responden menerima pesan dakwah yang disampaikan tetapi tidak menunjukkan reaksi tertentu. Alasan menerima karena menganggap isi pesan benar (sesuai tuntunan agama). Terkesan para responden ini hanya membaca sekilas, lalu tidak bersedia memikirkan lebih lanjut sehingga reaksi implisit tidak terdeteksi.

Tanggapan menolak dengan respons implisit marah sebanyak 18\%. Alasan mereka menolak dengan marah karena beberapa hal, yaitu (1) jika tidak dengan meminjam uang di bank tidak mungkin bisa membeli rumah, mobil, dan lain-lain; (2) berdakwah itu di masjid saja, tidak perlu diiklankan; (3) masih banyak hal "haram" lain yang meresahkan masyarakat yang sebaiknya diurus terlebih dahulu; dan (4) ibadah dan dosa tanggung jawab masing-masing.

Tanggapan menolak dengan yakin sebanyak 4\%. Penolakan ini disebabkan responden sudah memiliki sikap tersendiri dalam menentukan apa yang harus dilakukan dalam hidupnya. Responden sudah memiliki untuk melakukan perbuatan yang dinilainya memang harus dilakukan. Dengan sikap tegas responden menolak pesan iklan dakwah tentang riba yang marak di media massa.

Tanggapan menolak dengan respons implisit tidak peduli sebanyak 10\%. Sikap ini dinyatakan dengan pernyataan penolakan dan tidak bersedia memberikan alasan. Intinya, responden tidak menolak apa pun tujuan dan urgensi pesan dakwah tersebut.

Sebanyak $24 \%$ responden mengabaikan iklan dakwah tentang riba dengan reaksi implisit malu. 18\% lainnya mengabaikan dengan reaksi implisit enggan dan 4\% mengabaikan dengan reaksi implisit yang tidak terdeteksi.

Tanggapan mengabaikan responden dalam bentuk tindakan tidak mengindahkan. Responden yang mengabaikan dengan reaksi implisit malu cenderung membiarkan, meskipun terbersit keinginan untuk memperhatikan atau mempelajari lebih jauh tentang hukum riba dalam Islam.

Responden yang mengabaikan dengan reaksi implisit enggan ditunjukkan dengan sikap meremehkan. Keengganan tersebut diwujudkan dengan reaksi tidak peduli, bahkan tidak bersedia membaca iklan dakwah tersebut.

\section{PENUTUP}

Berdasarkan hasil penelitian disimpulkan bahwa iklan yang memuat dakwah tentang riba cenderung menggunakan bentuk tindak tutur asertif. Pesan dakwah asertif menyajikan nukilan ayat suci Al-Qur'an dan hadis Nabi Muhammad Saw sebagai sumber hukum yang dinilai sangat kuat untuk mendukung pesan.

Berdasarkan data yang diperoleh dapat dikemukakan bahwa responden cenderung "mengabaikan" pesan dakwah tentang riba karena tuntutan dan gaya hidup hedonis. "Keharusan" memiliki harta benda dengan cepat mengarahkan sikap responden pada sikap mengabaikan tuntunan Islam tentang riba.

\section{DAFTAR PUSTAKA}

Birner, B.J. (2012). Introduction to Pragmatics. Singapore: Wiley-Blackwell.

Cummings, L. (2007). Pragmatik: Sebuah perspektif multidisipliner. Terjemahan Abdul Syukur Ibrahim. Yogyakarta: Pustaka Pelajar (karya asli terbit pertama tahun 1999).

Kreidler, C. (1998). Introducing English Semantic. London: Routledge.

Leech, G. (1993). Prinsip-prinsip Pragmatik. Jakarta: Penerbit Universitas Indonesia (UI-Press). 
Littlejohn, S.W. dan K.A. Foss. (2005). Theories of Human communication. 8th Edition. Belmont, USA: Thomson Learning Academic Resource Center.

Mahanani, N. (2003). Periklanan Promosi Aspek Tambahan Komunikasi Terpadu. Jakarta: Erlangga.

Masran, S. (2018). Analisis Penggunaan Bahasa pada Papan Iklan di Kuala Lumpur (Kajian Sosiopragmatik). Al-Ishlah: Jurnal Pendidikan 10(2), hlm. 244-254. https://doi.org/10.35445/alishlah.v10i2.87

Prayitno, H. J. (2017). Studi Sosiopragmatik. Surakarta: Muhammadiyah University Press.

Rahardi, K. (2009). Sosiopragmatik. Jakarta: Erlangga.

Rahardi, K. (2015). Menemukan Hakikat Konteks Pragmatik. Makalah. Kajian Pragmatik dalam Berbagai Bidang, Seminar Nasional Frasasti II Program Pascasarjana Universitas Negeri Sebelas Maret Surakarta 2015, 1-10.

Rahmayanti, I. dan Alvi Fajar. (2020). Sosiopragmatik Imperatif Iklan pada Media Sosial. Diglosia 3(1), hlm. 79 86. https://doi.org/10.30872/diglosia.v3i1.37

Salvador, V. (2003). Pragmatics and Stylistics. Noves SL. Revista de Sociolingüística. Diakses dari http://www.gencat.cat/llengua/noves, 26 Agustus 2018.

Shofaa, F. dan Meina Astria Utami. (2017). Menyingkap Makna dan Tanda dalam Iklan Rokok A-Mild Versi "Hasrat": Sebuah Kajian Semiotika. Ranah 6(2), hlm. 180-197. https://doi.org/10.26499/rnh.v6i2.266

Syarief, M. I. (2011). Konsep Riba dalam Alquran dan Literatur Fiqih. Al-Iqtishad, 3(2), Juli 2011, hlm. 293-312. https://doi.org/10.15408/aiq.v3i2.2527

Wicaksono, A. (2015). Tindak Tutur Komisif Pementasan Drama "Mangir Wanabaya" (Suatu Kajian Sosiopragmatik). Ranah 4(1), hlm. 73-86. https://doi.org/10.26499/rnh.v4i1.26

Yule, G. (2016). Pragmatik. Terjemahan Indah Fajar Wahyuni. Yogyakarta: Pustaka Pelajar. 